Марк Пижик

$\mathrm{PhD}$, Координатор бази даних,

FLAME Project,

Прінстонський університет

(Прінстон, США)
Mark Pyzyk

$\mathrm{PhD}$, Database Coordinator, FLAME Project,

Princeton University

(Princeton, USA)

ORCID: 0000-0001-7542-4252

mpyzyk@princeton.edu

\title{
REGIONAL BIAS IN LATE ANTIQUE AND EARLY MEDIEVAL COIN FINDS AND ITS EFFECTS ON DATA: THREE CASE STUDIES
}

\section{РЕГІОНАЛЬНЕ ВІДХИЛЕННЯ У ЗНАХІДКАХ МОНЕТ ПІЗДНЬОРИМСЬКОГО ЧАСУ ТА РАННЬОГО СЕРЕДНЬОВІЧЧЯ ТА ЇХ ВПЛИВ НА ДАНІ: ТРИ ПРИКЛАДИ}

\begin{abstract}
.
This paper discusses the role of bias and uncertainty in the FLAME project (Framing the Late Antique and Early Medieval Economy) at Princeton University. FLAME is a large Digital Humanities project focused on collecting and storing data on coin minting and circulation in west Afro-Eurasia from 325 to $750 \mathrm{CE}$, roughly coinciding with the period of transition between the late antique and early medieval periods. The overarching goal is historical - that is, we wish to be able to say something new about how the world of late antiquity and the medieval period really was. However, in the process of building this database, and its accompanying online tools, we have also observed that the data is difficult and problematic. This paper, then, is an account of some of these historiographical and methodological issues in the form of three case studies (Britain, France, and Ukraine) and a short discussion of strategies that FLAME employs to communicate these biases to users, who benefit from a transparent discussion of messiness and difficulty in the data.

The paper proceeds in seven sections, of which the first is an introduction. Section Two presents basic technical details of the project, such as its database implementation (MySQL) and its online visualization systems (ArcGIS), access to which can be found at https://flame.princeton.edu. Section Three discusses the historiographic questions at stake, distinguishing between Primary Bias (inherent in materials themselves) and Secondary Bias (particular to national and political contexts).

Section Four, Five, and Six are each devoted to a separate case study: Britain, France, and Ukraine. Each discusses FLAME's data on that region and briefly touches
\end{abstract}


upon contextual factors that may bias regional data. Thus, Section Four discusses Britain, with much analysis focused on the role of the Portable Antiquities Scheme in incentivizing reporting of found antiquities, and its effects on coin data. Section Five discusses France, where FLAME records many coin finds, but from a limited time period (primarily from Merovingian states). Section Six discusses the situation in Ukraine, where we were helped by existing scholarly resources (such as the coin inventories of Kropotkin), but where cultural heritage preservation suffers from weak state enforcement and where much scholarship suffers from spotty recording practices, and often outright theft of national treasures, going back to the imperial Russian period. Section Seven concludes the paper, noting that such methodological and second-order discussion of bias is a critical desideratum for the Digital Humanities as it matures into its second decade.

Ключові слова: база даних FLAME, пізньоантична та ранньосередньовічна економіка, знахідки римських та візантійських монет, топографія нумізматичних знахідок.

\section{Анотація.}

У изй статті обговорюється роль відхилень та неточностей у проекті FLAME (Framing the Late Antique and Early Medieval Economy) у Прінстонськму університеті. FLAME - це великий цифровий гуманітарний проект, зосереджений на зборі та зберіганні даних про карбування та обіг монет у Західній Афро-Свразї з 325 по 750 роки нашої ери, щьо приблизно збігається 3 періодом переходу між пізньоантичним та раннім середньовіччям. Головна мета - історична, тобто бажання максимально відтворити те, яким насправді був світ пізньої античності та середньовіччя. Однак у процесі створення иієї бази даних та супутніх онлайн-інструментів ми також помітили, щуо дані виявилися складними та проблематичними. Отже, пропонована стаття становить виклад окремих історіографічних та методологічних питань у формі трьох блоків досліджень (Великобританія, Франція та Украӥна) та короткого обговорення стратегій, які використовуються у FLAME, щзоб повідомити про наявні відхилення користувачам $і$ в такий спосіб забезпечити їм можливість прозорого обговорення хаотичності та складності даних.

Стаття складається зі вступу та шести розділів. У першому розділі представлені основні технічні деталі проекту, зокрема реалізащія бази даних (MySQL) та системи онлайн-візуалізації (ArcGIS), доступ до яких можна знайти на https://flame.princeton.edu. У другому розділі розглядаються відповідні історіографічні питання з розрізненням первинної похибки (притаманна самим матеріалам) та вторинної похибки (особливо в начіональному та політичному контексті). 
Розділи третій, четвертий $i$ n'ятий присвячені окремим крайнам: Великобританії, Франщії та Україні. Кожен з них демонструє дані FLAME щуодо відповідного регіону та коротко торкається контекстуальних факторів, які можуть змішувати регіональні дані. Таким чином, у третьому розділі обговорюється Британія, при цььому багато аналізу зосереджено на ролі Portable Antiquities Scheme y стимулюванні звітності про знайдені старожитності та ї̈ вплив на дані щзодо монет. У четвертому розділові досліджусться Франщія, де FLAME фіксує багато знахідок монет, але з обмеженого часового періоду (в основному з держав Меровінгів). У n'ятому розділі обговорюється ситуаџія в Украйні, де ми використали наявні наукові ресурси (наприклад, інвентаризаційний опис монет Кропоткіна) i де збереження культурної спадщини страждає від слабкого державного контролю, а значна частина науковців страждає від неякісно зафіксованих знахідок, при чому часто відверто викрадених начіональних скарбів, починаючи $з$ імперської російської доби. Розділ шостий завершує роботу, де відзначається, щзо такого роду методологічне та другорядне обговорення відхилень критично бажане для цииррової гуманітарної науки у пору, коли вона дозріває до свого другого десятиліття.

Key words: FLAME coin database, Late Antique and Early Medieval Economy, Roman and Byzantine coin finds, numismatic finds topography.

\section{Introduction}

This paper discusses the role of bias and uncertainty in the FLAME project (Framing the Late Antique and Early Medieval Economy) at Princeton University. FLAME is a large Digital Humanities project focused on collecting and storing data on coin minting and circulation in west Afro-Eurasia from 325 to $750 \mathrm{CE}$, roughly coinciding with the period of transition between the late antique and early medieval periods. The goal is to provide a new base of evidence for historians of this period to use in economic, political, and social history. We build on the work of Chris Wickham, and especially his synthetic treatment of this period in Framing the Early Middle Ages: Europe and the Mediterranean 400-800. ${ }^{1}$

\footnotetext{
${ }^{1}$ Indeed, we are most indebted to his footnote at p. 702, n. 16, which confirmed the need to add this body of evidence to the discussion. His note reveals the limits of coin evidence, as well as hinting at its potential something we aim to clarify in our work: "I have relied on [numismatic evidence] less than on ceramics, in part to avoid an over-complex exposition; in part because it is often unclear how much coin distributions tell us about economics as opposed to the structures of public administration and of diplomatic gift exchange... in part because only copper coins, which were not minted in the post-Roman West, are much of a guide to nonluxury exchange in our period... It must be further observed that several moments of considerable economic prosperity show striking shortages of coin in excavations, such as the fifth century in Palestine, and the ninth century in both Rome and Iraq... All the same, coinage is a crucial indicator, and I would hope that future comparative studies give it proper weight."
} 
The overarching goal is historical - that is, we wish to be able to say something new about how the world of late antiquity and the medieval period really was. However, in the process of building this database, and its accompanying online tools, we have also observed that the data is difficult and problematic. This is undoubtedly true of all Digital Humanities data, but we felt - given the breadth of the project - that we were in a particularly good position to discuss these biases. This paper, then, is an account of some of these through three case studies (Britain, France, and Ukraine) and a short discussion of strategies (some only now being implemented) to communicate these biases to users, who will benefit from a transparent discussion of messiness and difficulty in the data. These biases are discussed in general in Section 3, and concretely in Sections 4, 5, and 6

\section{Technical Methodology}

In terms of data management, FLAME host all of our data on a MySQL server, using a standardized web forms to accept new entries from contributors as well as to edit existing entries. Using such a system, FLAME ensures uniformity among entries (e.g., in terms of spelling of denominations or geographic coordinates of mints). This has allowed us to increase our data in a manageable way, with minimal need to clean or smooth data after it has been entered.

The data is visualized using ESRI's ArcGIS, a standard mapping tool among archaeologists (and increasingly common among digital historians). Their ArcGIS Platform facilitates the web-based application by which FLAME's data is visualized and accessed by users on our website. ArcGIS was chosen because it provides ready tools for data visualization, including the ability to draw connections between mints and finds. This visualization is accessible through FLAME's website (https://flame.princeton.edu).

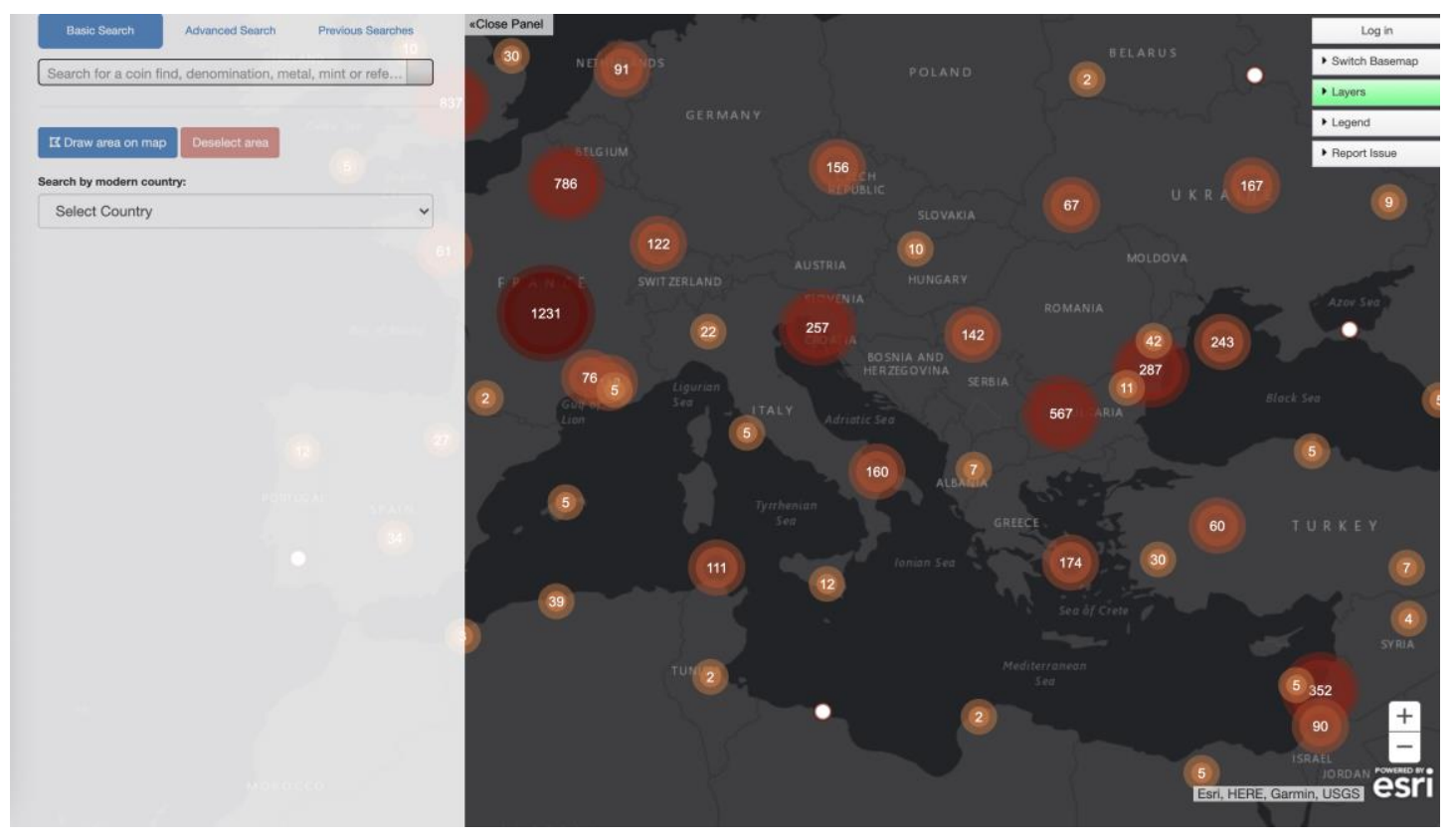

Default view on FLAME's Circulation Module map visualization 
Two complete projects are hosted there. The first is FLAME's Minting Module, which is largely outside of the scope of this discussion. Completed in 2016, it visualizes mints and minting activity across west Afro-Eurasia between 325-750 CE. It does not make connections to find spots, however, and relies on coin catalogues to establish basic information about coin issues and minting output rates. The Circulation Module, which is the primary focus of this paper, was started around 2017 and was launched in May of 2020. It currently involves the participation of more than thirtyfive international scholars, who contribute data and provide regional specialist knowledge.

\section{Historiographic Questions}

Among FLAME's primary interests is the question of systemic bias in its core data (as well as in external datasets it imports). Numismatists, in general, are accustomed to discussing some aspects of this bias (what we may call here Primary Bias) - for instance, the tendency of certain kinds of coins and not others to fall out of the historical record, by virtue of those coins' own characteristics. For example, gold coins tend to be valued more highly than other metals and are lost less often (and once lost tend to be recovered more avidly). We therefore find them far less often in excavations, which tend to return slices of everyday life, where coins fall out of coin purses and may or may not be retrieved (thus, bronze coins are better represented than gold or silver). Precious metal coins are more likely to crop up in hoard finds, which are usually buried specifically for the purpose of storing value.

However, other, more indirect biases (we might call these Secondary Biases), have not traditionally been treated explicitly in numismatic scholarship - or where they have, it has been in isolation. Among these, FLAME has found regional biases to be among the most challenging. Some of the most significant asymmetries do not stem from differences in circulation patterns in antiquity (though these are usually also relevant). Rather, they are more likely caused by differences in historical, political, cultural, or disciplinary circumstances in the modern period. While this paper touches upon the first category, the second is of more interest, in particulate because it remains understudied by numismatists.

One reason that FLAME itself has gravitated to the second category of bias is because of its large, international scope. FLAME's data currently includes coin finds as far apart as Portugal, central Siberia, southeastern India, and Ethiopia. In principle, there is no reason it could not extend, eventually, to China, where Byzantine coins appear among grave goods in certain tombs. Working across such boundaries has required core staff, especially, to deal with scholarship in several languages (where possible). It has meant that FLAME staff and contributors have had to ponder why one region differs from another, even when geographically close. And while regional specialists are often well aware of idiosyncrasies that affect their chosen domain (with experts on French coins knowing the French context very well, and Turkish 
numismatists knowing Turkey), these are seldom framed comparatively. Thus, the underlying causes of such bias remain rather mysterious to numismatists at large.

The best single example of a regional bias being explained by political, cultural, and institutional means is the unique case of Britain, where coin-finds are exceptionally well recorded and reported. Indeed, Britain has far more finds in FLAME than other, more central regions in the late antique Mediterranean economy, like Italy. We cover Britain in the next section, but the short explanation for this overabundance of finds can be found in institutional, legal, and contextual factors and in particular the existence of the Portable Antiquities Scheme, which facilitates and incentivizes the collection, cataloguing, and reporting of vast numbers of coin finds (as well as other archaeological discoveries) in England and Wales. This, of course, pushes the question back a step: Why does Britain have the PAS, and why don't others follow their example? This is a complicated, and sometimes fraught, question. This paper will not seek to answer it, raising as it does questions of the legal, cultural, and political idiosyncrasy of Britain, as well as its approach to heritage preservation. It will however consider the way that such a system distorts the reporting of British coin finds, just as heritage regimes in other countries (in this case, France and Ukraine) distort reporting there.

\section{Case Study 1: Britain}

British coin-finds are very numerous and well-documented. FLAME records 776 coin-finds, of which 772 are classified as coin hoards. ${ }^{1} 285,530$ coins are recorded as coming from 47 mints. Of these, Colonia Augusta Treverorum (modern Trier) was by far the most common, with 1,189 coin groups associated with this city, followed by Mediolanum (386), Rome (323), Aquileia (286), and Siscia (192). After this, one finds coins from mints further afield - Constantinople (122), Thessalonike (110), Antioch (95), and so on. This overrepresentation of more proximate mints (not at all unexpected) applies to gold coinage as well as bronze. ${ }^{2}$ That none of these come from British mints is not surprising - the mint of London ended production in the reign of Constantine and had no British rivals. Production of tremissis coins at mints such as Canterbury and Bury began again only in the mid-sixth century.

More than in any other region, British coin-finds can be considered to be broadly representative of the state of play in the late antique and early medieval economy. This is particularly so because of the quality of reporting in the British context, coming together from a distributed system of reports, usually by private individuals (often enthusiasts known as "detectorists"). The basis for this is the Portable Antiquities Scheme (PAS), launched in 1997. PAS operates out of the British

\footnotetext{
${ }^{1}$ This classification is PAS's own. We were initially surprised by this result, as a very significant proportion of these finds are reported by private detectorists, in ones or twos - rarely as a more significant hoard. Nevertheless, we left the status of these finds as reported, as a more substantive program of corrections would take undue labor on our part. It is hoped that this is corrected on PAS's side, in future.

${ }^{2}$ In the case of gold, 134 groups were comprised of coins minted at Trier, 97 at Mediolanum, 28 at Ravenna, and 24 at Constantinople. In the case of bronze, 392 coin groups were comprised of coins minted at Trier, 140 at Rome, 129 at Aquileia, 117 at Siscia, and then 65 at Constantinople.
} 
Museum, which coordinates thirty-six "find liaison officers" based in geographical districts around the country. Detectorists must declare objects discovered to PAS. When they do, the objects are offered to museums for purchase at market prices - if no museum buys, they are returned to the finder. And while this system has incentivized reporting, there have still been cases in which significant finds (for instance, of a Viking hoard found in Leominster in 2020) have gone unreported. ${ }^{1}$ We know about these because they resulted in prosecution. Others instances, however, have likely gone unnoticed. Nevertheless, it is very likely that more finds are reported in Britain than elsewhere, which likely has much to do with the incentive structure of the PAS.

In discussing Britain, it should also be said that there are distinctions even among constituent countries. England and Wales participate in the Portable Antiquities Scheme (henceforth, PAS), while Scotland and Northern Ireland do not. This difference can immediately be seen in FLAME's map of British coin-finds, with Scotland and Northern Ireland largely empty. This, of course, is not to say that such finds do not exist. It does mean, however, that they have not been assembled in the central and standardized format that southern British coin finds have, which has made it easy for FLAME to access and import.

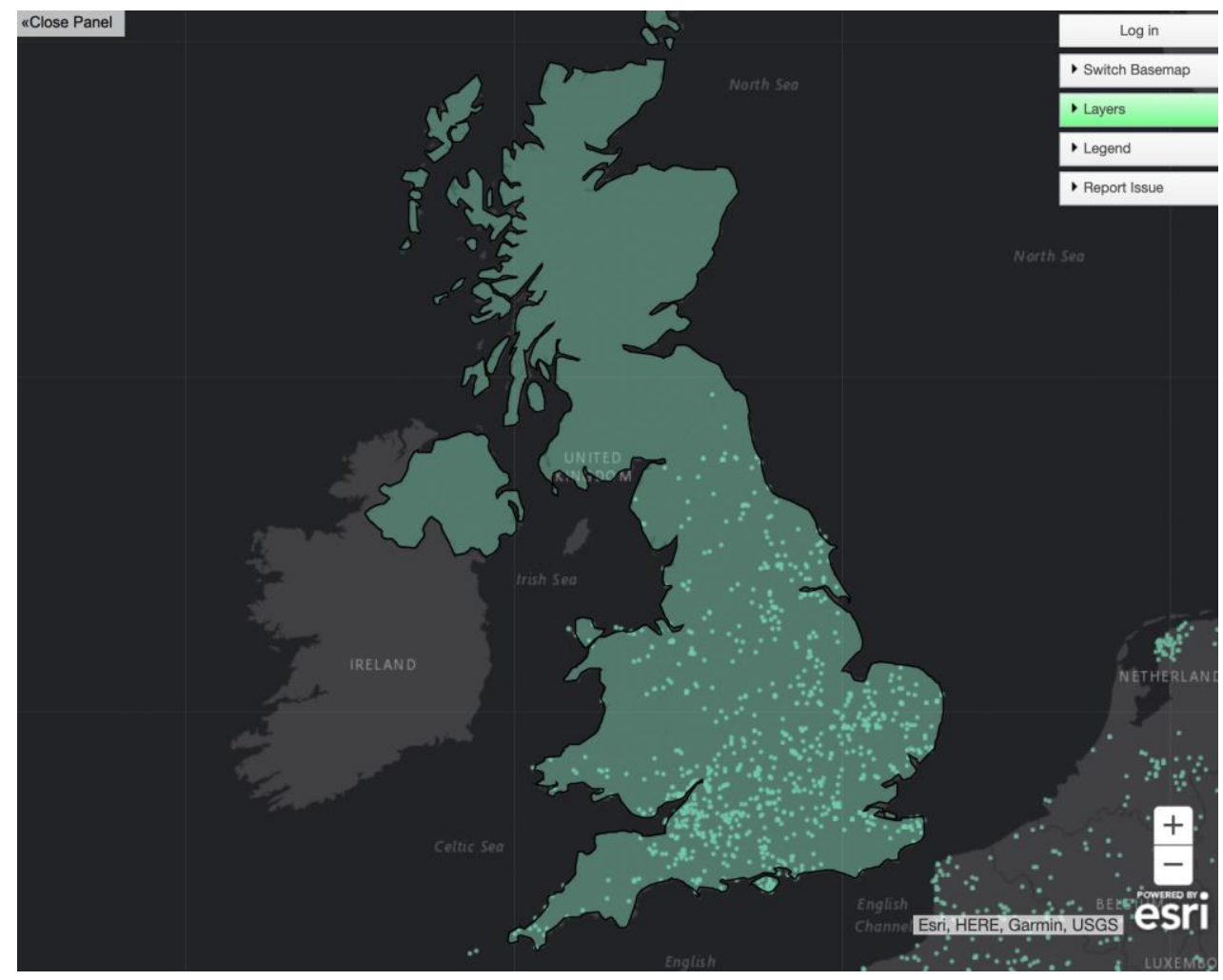

British coin-finds in FLAME

But the coverage within Britain is most remarkable when viewed against that of other countries. We have already mentioned the overrepresentation of the UK when

${ }^{1}$ Mead 2020. 
compared to more central regions of the Mediterranean, specifically Italy. This is true also of other significant economic centers, like Iberia, Anatolia, and North Africa. Such overrepresentation is generally a matter of common knowledge in numismatic scholarly circles. However, in FLAME, we can see it quite concretely. In terms of FLAME's database, this overrepresentation is almost entirely due to the existence of the PAS, beginning with its effect of incentivizing reporting, but continuing through the resources devoted to identifying, cataloguing, and finally publishing the findings online as data, free to access (and in the case of FLAME to import wholesale).

\section{Case Study 2: France}

France is also very well covered in the FLAME database. In absolute terms, there are more coin-finds from this region than any other major region (932, as compared to the UK's 776), with 205 being classed as hoards, 76 as excavations, and the rest single-finds. However, compared to the UK's 285,530 coins, France yields only 50,657. The fact that so many of these come in the form of single finds is remarkable considering French laws governing moveable objects and heritage (see below). The most common mints are intra-regional, with Arles (230), Lugdunum (modern Lyon, 229), and Trier (171) being most common, followed by more distant mints such as Rome (134) and Constantinople (85). Unlike Britain, only a tiny number of coins made their way to late antique and early medieval Gaul from eastern centers such as Antioch (7) or Thessalonike (3).

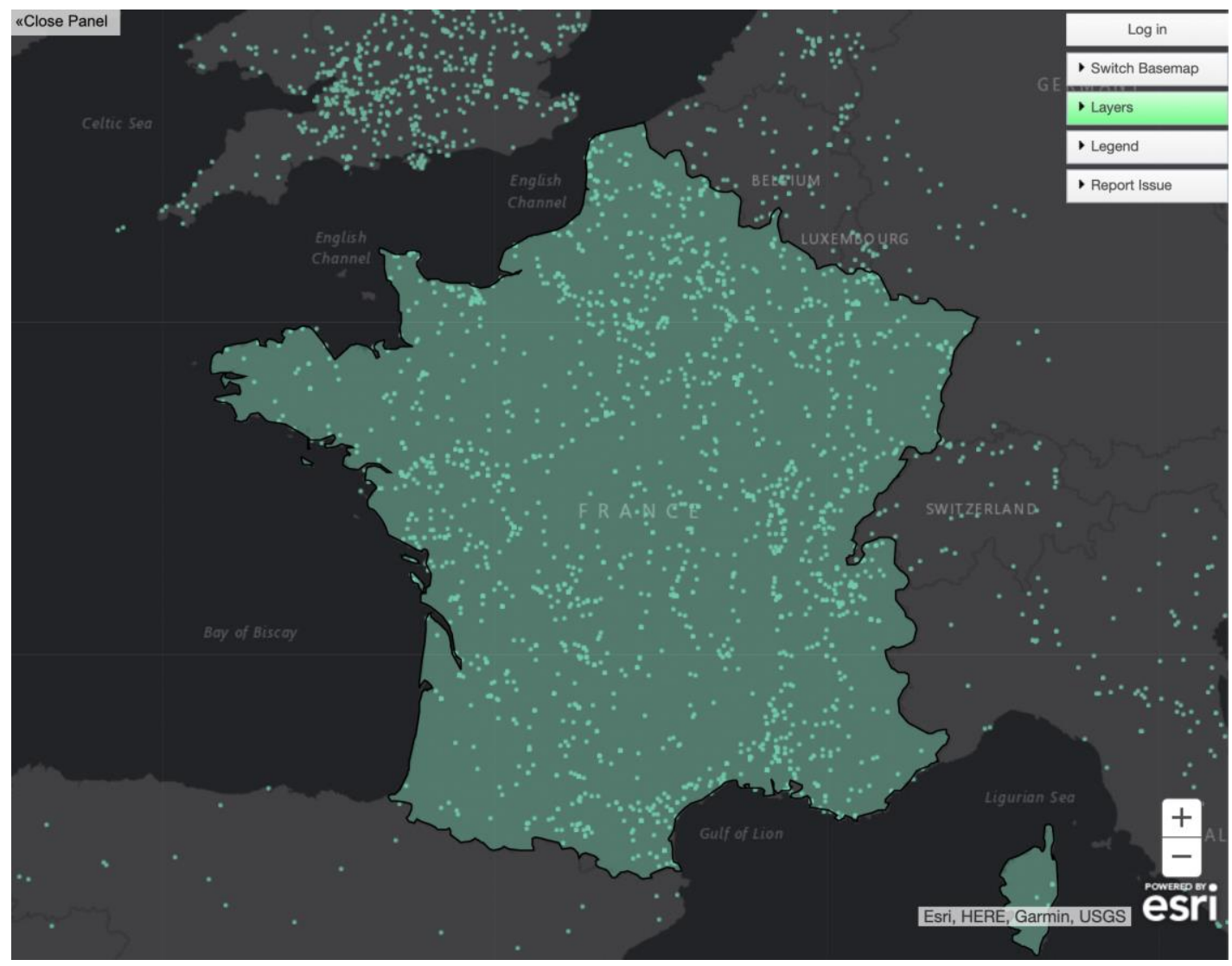

French coin-finds in FLAME 
The French story is complicated by the state of scholarship and publication. Unlike the UK, no institutional solution such as PAS exists, and despite the high number of finds from France, as a picture of economic activity from 325-750 CE, what is published (and especially what is catalogued in inventories of coin-finds) is chronologically uneven. Thus FLAME, rather than drawing on a large, comprehensive database of coin finds, relies heavily on a few idiosyncratic works of scholarship. The most prominent of these is Jean Lafaurie and Jacqueline Pilet-Lemière's Monnaies $d u$ haut Moyen Âge découvertes en France, Ve-VIIIe siècle. This was Lafaurie's final publication, and was incomplete when he died, being finished by Pilet-Lemière and published as the eighth entry in the Ernst Babelon series. This volume focuses on Merovingian coins of the 5th to 8th centuries. FLAME therefore has a chronological bias at the heart of its French data, since no clear analogue to Lafaurie and PiletLemière exists for late Roman coinage.

This has implications even for cursory examination of the FLAME's data. We noted above, for example, that there were very few long distance mints represented among the French (really, Merovingian) finds. More late antique finds would likely change this, since the absence of eastern Mediterranean coins stems from the fact - as noted by Lafaurie and Morrison in another work - that Merovingian mints tended to repurpose gold coinage, new or old, to be re-issued for Frankish rulers. ${ }^{1}$ If FLAME had fuller coverage of the late Roman period, for instance, some of this geographical imbalance would look different.

These differences are compounded by differences in the French approach to heritage preservation and publication of finds. French heritage laws, for instance, are quite strict on the topic of detectorists, for example, allowing for amateur discovery of archaeological goods only in cases where it can be proven the goods were discovered by accident. Thus, while the dispersal of "treasure" goods is governed by the French Civil Code, ${ }^{2}$ which allows the owner of the property to keep half of the findings and the one finding the object to keep half - so long as the object is discovered through "pure chance" - the Heritage Code declares this ownership to be legitimate only if the state is made aware of it and does not wish to claim the object itself. Should it wish to, there is a clear procedure for expropriating it, with compensation set by an expert appointed by the government. ${ }^{3}$

The merit of the French system is, arguably, that it lowers the incentive to loot by removing ambiguity over how and when detectorists can try to find archaeological objects (realistically, almost never without state permission). However, from the other side, there is arguably more incentive in France to keep discoveries - deliberate or fortuitous - out of view of the state. This has meant, occasionally, quite spectacular arrests of looters/detectorists - as recently occurred in the case of an anonymous

\footnotetext{
${ }^{1}$ Lafaurie \& Morrison 1987; Metcalf 2006, 338.

${ }^{2}$ Civil Code $\$ 716$.

${ }^{3}$ Heritage Code $§ 541-8$.
} 
Frenchman known only as Patrice T. ${ }^{1}$ The French government is quite ardent in its pursuit of such figures, however, mandating up to seven years in prison and up to $€ 100,000$ in fines. It is not yet clear if this legal structure is responsible for the large number of single finds in FLAME's French data - almost certainly chance finds that were duly reported to local officials.

\section{Case Study 3: Ukraine}

Our final case study is Ukraine, which has fewer finds than France or the United Kingdom, but is nevertheless a prominent and well-covered region in the FLAME database. ${ }^{2}$ FLAME records 349 coin-finds, of which 37 are hoards, 47 come from excavations, and the rest are single finds. Most of these coins came from the mint at Constantinople (83), followed by Chersonesus (34), Nikomedia (13), Siscia (10), and a series of increasingly distant locations. This includes some finds whose coins traveled a considerable distance - for example, an early 4th century hoard found in Kolomyia, in western Ukraine, which contained coins from London and Trier. ${ }^{3}$ Unlike the previous two regions, however, it is distinguished by a very high number of unknown mints, with totally unknown mints numbering 192, and those that can be traced at least to the eastern Mediterranean numbering 134.

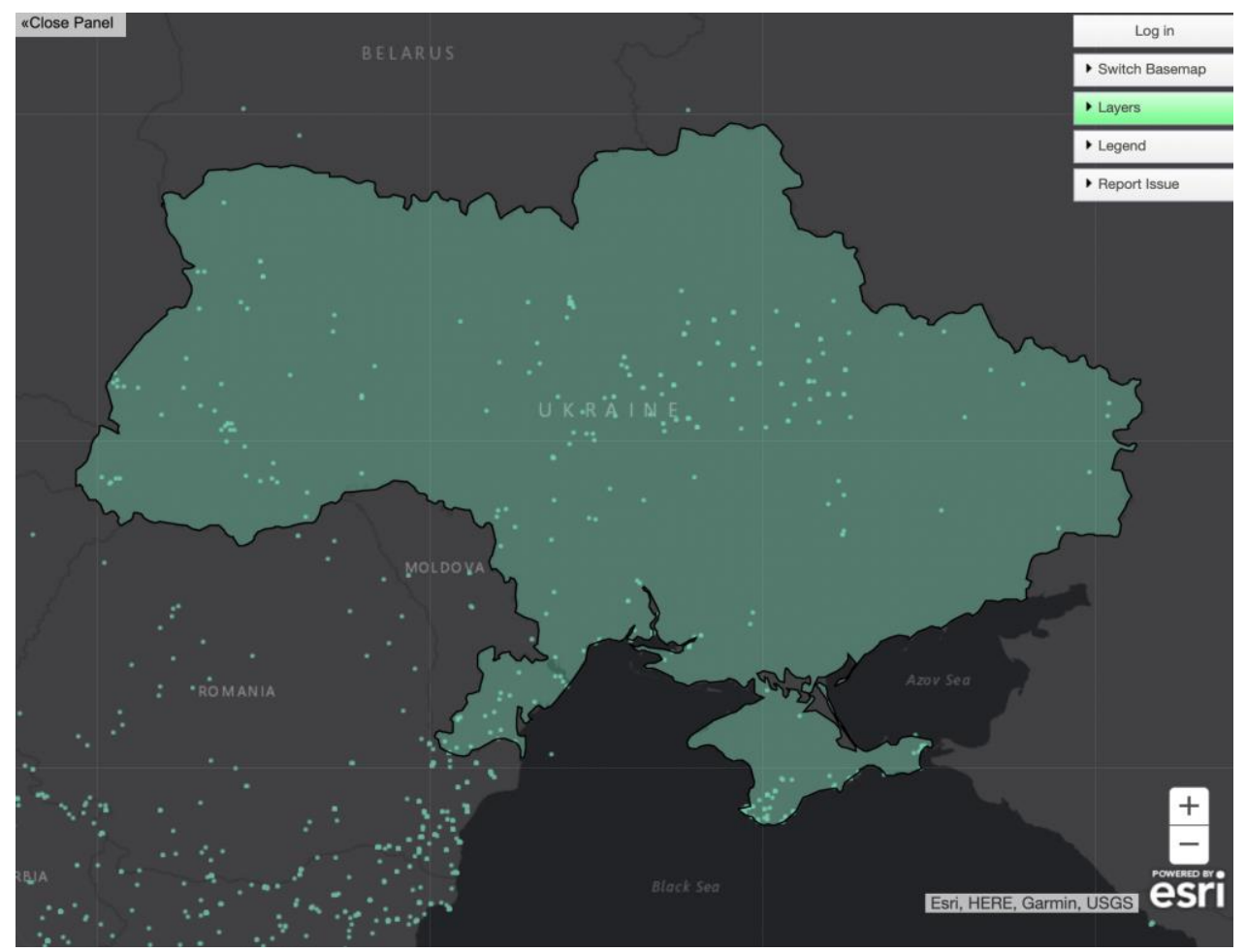

Ukrainian coin-finds in FLAME

\footnotetext{
${ }^{1}$ Davis-Marks 2020.

${ }^{2}$ A major reason for this is the participation of several Ukrainian scholars as part of a Ukrainian team. This includes Prof. Vasyl Orlyk (Central Ukrainian National Technical University), Andrii Boiko-Haharin (Senior Curator, The National Bank of Ukraine), and Elena Petrauskas (Assistant Researcher, The Institute of the History of Ukraine at the National Academy of Sciences). Their participation was made possible through funding given by the Canadian Institute for Ukrainian Studies.

${ }^{3}$ Braichevsky 1961, 76.902 .
} 
The Ukrainian case, like the British and French, is idiosyncratic. Like the French, any effort at data gathering and large-scale publication of finds is undertaken by individual scholars. There is no Ukrainian PAS. Thus, we relied heavily on particular scholarly inventories, which made our work possible. In particular, the coinfind inventories of Vladislav Kropotkin, undertaken in the 1960s, covering the entire Soviet Union, were invaluable. ${ }^{1}$ We have supplemented this with more recent coin finds, which appear in more disparate venues - academic journals, conference proceedings, etc. The coverage is more or less even, chronologically.

Unlike France, Ukraine's heritage institutions have considerably less funding and support to ensure that findings are reported and protected. And while moveable heritage objects (such as coins) receive legal protection - including in the constitution of the country, but most particularly under the Law on the Protection of Cultural Heritage - it is widely acknowledged that enforcement is, at best, spotty. ${ }^{2}$ It is widely acknowledged that looting is common, and unlike in the UK or France, a large number of coin-finds make their way into private collections, largely without consequences. It means that the preservation and cataloguing situation is quite dire, with information on coin provenance, associated mints, denomination, and sometimes even quantity being spotty, at best.

Even older finds - for instance, those common in the works of Kropotkin present considerable challenges. As we noted, a very significant proportion of mint assignations in FLAME within the territory of Ukraine must be considered unknown. This is because much of the reporting of finds was done haphazardly, locally (with private citizens reporting findings). In many cases, they reported to local authorities, and finds subsequently either disappeared or were dispersed (to where and to whom, often unknown). In other cases - from the Russian imperial and Soviet periods - finds were deemed significant enough to be sent to larger museums outside of Ukraine (for instance, to St. Petersburg or Moscow). In these cases, too, they were not sufficiently catalogued or published, and many have subsequently disappeared (whether because they were destroyed or because they remain at the bottom of a vault somewhere). In any case, FLAME is unable - even if had it the resources - to research and assign mints to these coins. Unlike the UK and France, Ukraine's problems are at least partly the result of its status, not as imperial center, but as a periphery whose heritage and moveable treasures were looted and taken elsewhere.

Conclusion. We looked at three regions covered in the FLAME database. Each presents a considerably different picture of coin circulation during 325-750 CE. Such differences are, to a significant degree, rooted in differential patterns of historical economic activity (Primary Biases). We did not, however, concentrate on such factors very strongly in this paper, partly because such comparative accounts require considerable attention and effort to expound effectively. More to the point, we wished

${ }^{1}$ Kropotkin 1961; 1962; 1965; 1966; 2000.

${ }^{2}$ Safanov \& Datsko 2020. 
to concentrate on the historiographic questions that were raised in the course of gathering and encoding FLAME's data (Secondary Biases), because this is the other, less well-known, vector by which such inter-regional differences emerged in FLAME - that is, our data is afflicted by systematic, long-term biases that manifest primarily at the national level. These biases are based in particular national histories, which give rise to particular legal, cultural, and social regimes that conditioned divergent outcomes in excavation, preservation, cataloguing, and publication of coin-data.

Thus, while numismatists largely share an overarching scholarly culture (albeit speaking and writing in many different languages), their work was and is affected by distinct national factors largely beyond their control. And while this is to some extent an obvious insight, FLAME provides opportunities to render such differences explicit and comparable. In the field of visualizing uncertainty, for example (a growing and persistent companion to the runaway growth of the Digital Humanities since 2010), much attention is paid to certainty - among specialists, in documentary sources - as an unstable element that must be grappled with. ${ }^{1}$ Our point is that the evidentiary picture is even more complicated than this, and that humanistic data projects must consider such decentralized, systematic biases that affect fields of knowledge differently in different regions.

These findings are preliminary and make minimal conclusions about the relative balance between Primary and Secondary factors in shaping what we see in FLAME. Future projects should select case studies that, for example, shared ancient economic ties but whose political history diverged sharply in modernity (fault lines between the Soviet and non-Soviet spheres in the 20th century, or between certain Middle-Eastern countries, provide potential examples). Such cases should help to sharpen contrasts and gain insight into how different biases affect coin representation.

FLAME has already implemented some measures to communicate bias in its data. Our online tools, for instance, contain visual cues meant to point users' attention to systematic data bias. To begin, we have identified primary biases, such as Loss Bias, a category of differential preservation of coins based upon their perceived value - and indirectly, therefore, on their metal content. Thus, coins of high value (of gold or silver, for instance) are infrequently lost and display what we call Low Loss Bias. We have auto-categorized every coin find in our database according to such criteria, and make them available to users through a strategically placed exclamation mark, encircled in yellow.

${ }^{1}$ Bisantz, Marsiglio, \& Munch 2005; Windhager, Salisu, \& Mayr 2019. 


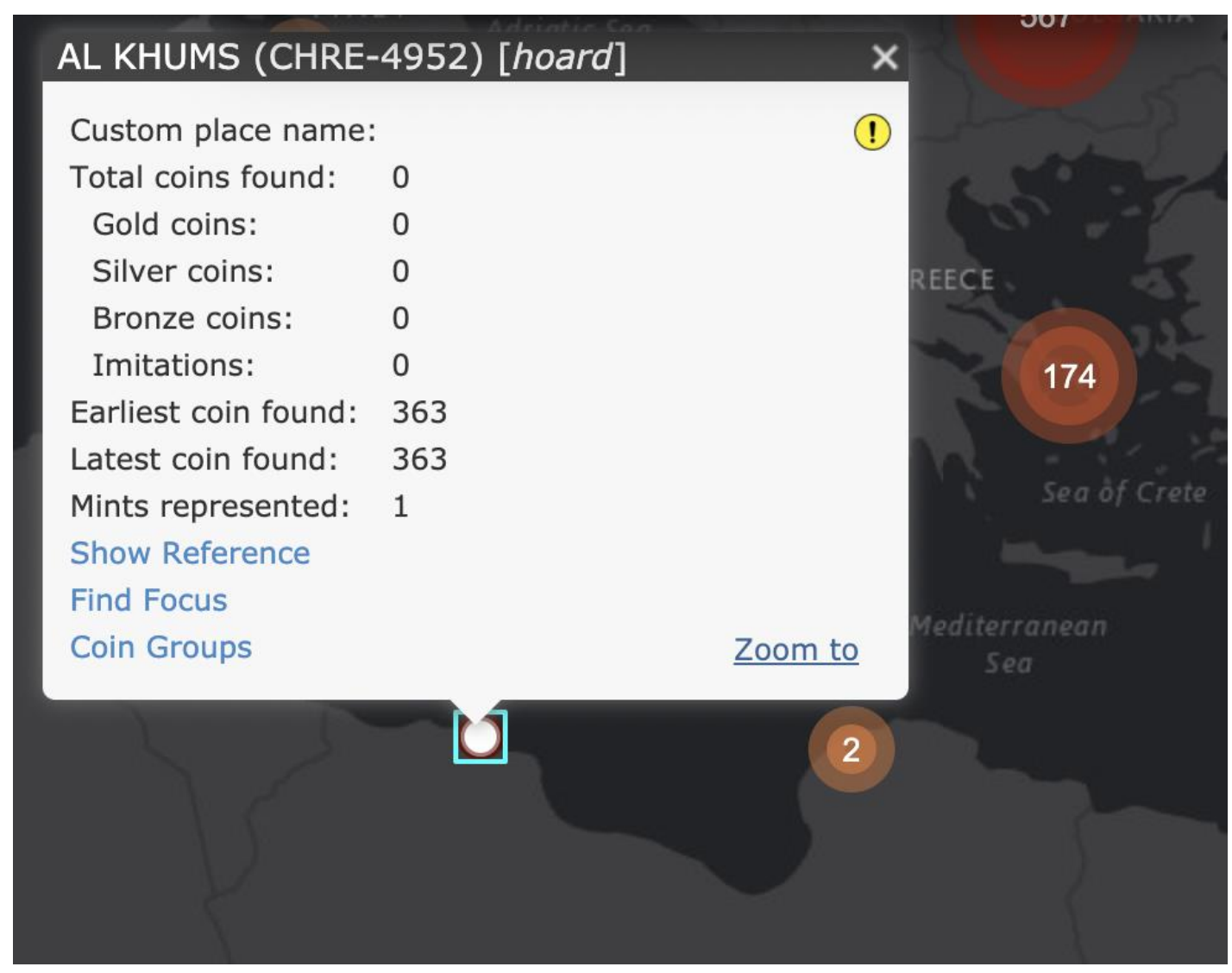

Primary bias visualized in FLAME

Nevertheless, the national and regional biases that we have discussed in this paper are not so easily pointed out. Rather than attempt to visualize them on our map of coin finds, we have commissioned a series of short essays on major coin regions. Thus, papers will cover biases in coin circulation in regions like Britain, France, and Ukraine, but also on the Iberian peninsula, Greece, Turkey, Italy, Syria, and other zones where we consider it critical for users to understand the unique circumstances that shape patterns of circulation. Consequently, it is hoped that they will better judge the ways in which such differences are, or are not necessarily, rooted in the real shape of ancient economic life.

\section{Bibliography}

Bisantz, Ann M., Stephanie Schinzing Marsiglio, and Jessica Munch. "Displaying Uncertainty: Investigating the Effects of Display Format and Specificity." Human Factors 47, no. 4 (Winter 2005): 777-96.

Брайчевський [Braichevsky], Михайло Юліанович. “Нумізматика в темах давньої історії східнослов'янських племен." [Numismatics in matters of ancient history among east-Slavic tribes] Історичні джерела та їх використання [Historical sources and their use], no. 1 (1964): 141-65.

Davis-Marks, Isis. "Officials Seize 27,400 Artifacts Looted by a Single French Treasure Hunter." Smithsonian Magazine. Accessed September 14, 2021. 
https://www.smithsonianmag.com/smart-news/french-officials-seize-more-

27000-looted-archaeological-artifacts-180976590/.

Кропоткин [Kropotkin], Владислав Всеволодович. “Дополнение к списку находок римских монет." [Additions to an inventory of Roman coin finds] Археология и культурная антропология [Archaeology and cultural anthropology], no. 6 (2000): 20-117.

Клады византийских монет на территории СССР. [Finds of Byznatine coins on the territory of the USSR] Издательство Академии наук СССР. Свод археологических источников (САИ), Вып. Е4-04. Москва: Институт археологии Академии наук СССР, 1962.

Кладь римских монет на территории СССР. Издательство Академии наук CCCP. [Finds of Roman coins on the territory of the USSR] Москва: Институт археологии Академии наук СССР, 1961.

“Новые находки византийских монет на территории СCCP." [New finds of Byzantine coins on the territory of the USSR] Византийский Временник 26 (1965): 166-89.

“Новые находки римских монет в СССР (дополнение к 'Своду археологических источников', вып. Г4-4).” [New finds of Roman coins in the USSR (additions to the Collection of Archaeological Resources)] In Нумизматика $u$ эпиграфика [Numismatics and Epigraphy], VI:74-102. Москва: Наука, 1966.

Lafaurie, Jean, and Cécile Morrisson. "La pénétration des monnaies byzantines en Gaule mérovingienne et visigotique du VIe au VIIIe siècle." Revue Numismatique 6, no. 29 (1987): 38-98. https://doi.org/10.3406/numi.1987. 1899.

Mead, Rebecca. "The Curse of the Buried Treasure." The New Yorker, November 9, 2020. https://www.newyorker.com/magazine/2020/11/16/the-curse-of-theburied-treasure.

Metcalf, David Michael. "Monetary Circulation in Merovingian Gaul, 561-674. A Propos Des Cahiers Ernest Babelon, 8." Revue Numismatique 6, no. 162 (2006): 337-93. https://doi.org/10.3406/numi.2006.2813.

Wickham, Chris. Framing the Early Middle Ages: Europe and the Mediterranean 400800. Oxford: Oxford University Press, 2005.

Windhager, Florian, Saminu Salisu, and Eva Mayr. "Exhibiting Uncertainty: Visualizing Data Quality Indicators for Cultural Collections.” Informatics 6, no. 3 (September 2019): 29. https://doi.org/10.3390/informatics6030029. 